\title{
Editorial
}

\section{AN ARGUMENT FOR HAVING OFFICE-SUPPORT STUDIES IN THE UNIVERSITY SYSTEM}

\author{
VIRGINIA SULLIVAN* and R. KENT YOUNG $\dagger$
}

\begin{abstract}
The authors argue that, rather than abandoning education in secretarial/office administration disciplines, universities should be leading the educational transformation required to prepare personnel to exploit the potential of computerbased technologies. Four points support the argument. First, computer-based office technologies capture data and make it available to creative users who can use it for innovative purposes. This "informating" process requires intellective skill development for all knowledge workers including office-support personnel. Second, the rapid changes being forced on organizations require flexible, intellectually developed personnel to support manager-leaders in the tasks of maintaining competitiveness in the 1990s and beyond. Third, as the stereotypical authoritarian, boss-secretary relationship changes toward a partnership relationship, office-support personnel will need the intellectual foundation provided by a university education. Finally, as a key contributor to the knowledge-intensive information management team, office-support personnel require a university education to ensure career mobility as they mature in their skills.
\end{abstract}

Rapid product and process innovation in the context of a highly interdependent global economy have characterized the 1980 s and are expected to characterize the foreseeable future for business organizations. These trends are feeding on and being driven by advances in information technologies, including computer-based data support and communications. ${ }^{1}$

We believe that rapid change in business organizations directly affects the secretarial/office-support role and argue that education for that role must take place in universities if the substantial benefits of information technologies are to be realized.

Our concern about education for the office-support role was stimulated by our participation in the review of a Secretarial Arts Department at St. Francis Xavier 
University, a small undergraduate university, and the subsequent decision by the University Senate to close, rather than transform, the department. A sister institution, Acadia University, and several American universities have also recently discontinued secretarial or office administration programs. Other universities have eliminated the name "secretary," added computer and communication courses, and dropped the teaching of shorthand in an effort to transform their programs to meet the demands of the 1990s. The University of Western Ontario, which had taken that route also, is phasing out its Administrative Office Management Studies program and replacing it with Administrative and Information Studies.

Several factors militate against locating office administration studies in universities - the low status of pragmatic studies among university faculty in the arts and sciences, conventional wisdom in both universities and governments that pragmatic studies are essentially procedural training which should be done on the job or in community colleges, a lack of consensus on the related issue of whether liberal arts applies to subject content or teaching process or both, pressures on universities to find ways to eliminate departments and so reduce expenses, and the obsolescence of many university programs in secretarial studies. On the last point, most secretarial arts programs have concentrated too long on keyboard and shorthand skills, which claimed time in the curriculum but had little credibility as university disciplines. Now, however, with the new computer and communication technologies, keyboard and shorthand skills have become less important than intellectual and interpersonal skills.

The prevailing attitudes toward secretarial/office-support studies may have been appropriate for an industrial era, but that era has evolved to a service/ knowledge era. We believe that offering strong university programs in officesupport studies is vitally important for the foreseeable future for both organizational productivity and the personal mobility of those who are inclined to start their career in office administration. The demands of computer-based technologies, and the impacts of these technologies on the contributions and the roles of office-based personnel - managers, technical professionals, and support personnel - all point to the need for increased levels of education for all "knowledge" workers, including support personnel. A comment by Raymond Cairns, Vice President of Information Systems at DuPont, a company on the leading edge of exploiting information technologies, is instructive:

My secretary now does spreadsheets and graph presentations, graphics and things like that. But her role is different today than it was eight years ago. And I think ten years from now it's going to be significantly different than it is today. And I think my role will be different. ${ }^{2}$

We will develop our argument for teaching office administration studies in universities by examining four features of the work setting of the 1990s: the availability of "information" technologies, the need for "learning" cultures in organizations, major changes in the administrative support role, and the 
importance of career mobility for those who want to start their careers in office administration.

\section{INFORMATING TECHNOLOGIES}

During his career as executive in charge of computer systems at Xerox, Paul Strassmann developed important insights into the transformative potential of computer-mediated technologies. In Information Payoff: The Transformation of Work in the Electronic Era, Strassmann traced the evolution of the dominant work in the economy through four eras - hunting, with nature as the principal resource; agricultural, with land as the principal resource; industrial, with capital as the principal resource; and service, with information as the principal resource. He speculated that productivity gains in our time will be realized through continual learning and that the most important investment will be applied to educating "human capital."

Strassmann contended that the work practices and organization structures which were effective in the recent industrial era will be different from those needed for success in a service-centred economy. Highly supervised, simple, standardized and socially unrelated jobs which served industrialization well will have to give way to jobs that demand individual competence, variety, autonomy, and learning if productivity gains are to be realized.

Strassmann also argued that information technology is upgrading organizational roles. He speculated that executives will be upgraded from "investors" to "planners," managers from "coordinators" to "investors," and professional and technical personnel from "specialists" to "generalists" in the delivery of information services. The office-support role will be transformed to include "many of the specialist activities now performed by the professional and technical workers."

In a 1982 paper, "Intellectual Technologies: The Key to White-Collar Productivity," Kathleen Curley and Philip Pyburn foresaw the shift in technology from the industrial era to the information (service) era, and its meaning for the office and for education for the office. They distinguished "industrial" technologies from "intellectual" technologies. Industrial technologies need "Type A" learning; that is training in a "predetermined set of skills that can be specified $a$ priori and standardized." Such procedural training is appropriate for the technologies of the industrial era office - typewriters, shorthand dictation, paper filing - and such training characterized the obsolete programs in secretarial studies in universities. On the other hand, the programmable, computer-based intellectual technologies are limited only by the imagination of the user and make possible an expansion of the intellectual power of the user. Intellectual technologies require both Type A and Type B learning - Type A to operate the machine (a challenge which is decreasing as icon-driven computer interfaces are becoming the norm) and Type B to develop insights into the application. Type B learning is the 
analytical and conceptual learning that facilitates the ongoing adaptive, innovative application of the machine. The precise outcomes of Type B learning cannot be specified in advance because of the intervening variable of the operators' imagination and know-how. A university education develops the foundations for Type B learning.

Shoshana Zuboff added insight into the creative and disruptive potential of the technological transformation that is in progress for the foreseeable future. Her book, In the Age of the Smart Machine: The Future of Work and Power, is based on longitudinal studies of computer-mediated work in several organizations. Zuboff distinguished between the "automating" and "informating" potential of computer-based technologies. Toward the end of the industrial era, prior to the application of the microchip in computer technologies, computers were used to automate - to replace human effort in both clerical and industrial settings. ${ }^{3}$ Zuboff used "database as organizational surrogate" to focus attention on the potential of computers to capture, accumulate, and display fine-grained data which map commercial and product-development processes. She coined the term, "informating," to account for the work of intelligent, creative users who are able to see patterns in these data. Insights arising from intelligent inquiry into these patterns leads to process and product innovations. The informating potential of computer technologies enables smart users to achieve the gains in competitive ability productivity and innovation - needed for survival in the 1990s.

The dual focus in the application of technology - automate/informate - reflects a duality in the use of personnel between the deskilled people who tended smart machines towards the end of the industrial era, and the smart people who use smart machines to their potential in the current information era.

The effective use of information technology and the capability to adapt competently to changes in work patterns and relationships demand smart users at all levels in the office, including those who provide executive and management support. Office support personnel have regular involvement with all the data in the office and should be expected to interact intelligently with managers and executives on issues arising from their insights. These people need what Zuboff termed "intellective" skills - ability to think abstractly, to use inductive reasoning, and to conceptualize. Intellective skills are the product of a university education.

\section{THE LEARNING ORGANIZATION}

In Dynamic Manufacturing: Creating the Learning Organization, Hayes and his co-workers at Harvard University used the term "learning organization" to direct attention to the essential quality of manufacturing organizations that have the adaptability to survive in the economy of the 1990s. "Learning organizations" are committed to achieving continuous increases in customer value, simplicity of operations, and internal discipline. Hayes et al. believe that "learning organization" is the appropriate focus for all organizations, faced as they are with rapid 
changes in financial markets, competitive scope, technological possibilities, and changes in organizational structure and processes. "Learning organizations" demand a high degree of intellectual input and commitment to learning from all employees.

Based on a study of sixteen major corporations, Rockart and Short of the M.I.T. Sloan School of Management's Center for Information Systems Research found that the role complexity of the senior manager's job is increasing as a result of the increased pace of organizational change and the manager's need to cope with unclear lines of authority and decision-making. These manager-leaders need competent management of their offices while they are concentrating on the strategic, external aspects of their responsibilities, and planning the changes that are needed to maintain competitiveness.

The office-support person/administrator is involved with two dynamic core aspects of the office operation - the exploitation and development of the office support technologies (generally computer-based data management and communication technologies) and the complex set of relationships and tasks. Hence, the office-support person needs the conceptual, analytical, and relationship skills that are associated with a university education for effective interaction with both the technical specialists who will be involved with the ongoing development of the office-support technologies, and the network of people on whom the manager/ executive depends.

\section{EVOLUTION OF THE SUPPORT ROLE}

It is fashionable to denigrate the office-support role by arguments involving the concept of subservience and the inappropriateness of universities educating for subservience. Office support in the context of industrial-era technologies mechanical typewriters and shorthand - did lead to subservient relationships. In Men and Women of the Corporation, Rosabeth Kanter described how role expectations developed early in the 1900 s as the growth of large corporations in the industrial era demanded professional managers. The ideal manager was toughminded, rational, analytical, and usually male. Women entered offices as stenographers, typists, bookkeepers and clerks. A "secretarial" (support) role emerged that was people-oriented and nurturant. Kanter speculated that the secretary-manager (boss) relationship was "an instance of the retention of patrimony within the bureaucracy." Under such patrimonial conditions, the mobility, salary, and power of the secretary were determined mainly by the boss' status and whim, rather than by education, experience, or skill. Kanter believes that the secretarial support role became characterized by parochialism, timidity and self-effacement, praise-addiction, and emotionality. It is little wonder, then, that the secretarial role and secretarial education, both of which have not yet reflected the new possibilities in the office, are held in such low esteem by students, academics, and many managers whose opinions have been formed by 
success with the older technologies. A role relationship closer to partnership than to boss-subordinate is required to realize productive potential, as Walton ${ }^{4}$ has argued in the context of the relationship of other professionals to managers. The formation in the intellective skills which are necessary for constructive work in both the technical and relational aspects of a partnership role requires a university education.

\section{CAREER MOBILITY}

We have argued that the office-support person is a key contributor to the knowledge-intensive information management team. Developing the intellective skills for effective contribution requires more education not less. Furthermore, young people, whether male or female, who want to contribute their talents to office support and build a career in office administration should be able to obtain their educational foundation in a university so that they are not limited by educational qualifications when they are ready to take on other responsibilities in the organization.

The educational foundation for competent office administration cannot be obtained through university programs in Business Administration and Information Systems. These programs are oriented in the first case to general management foundations and in the second case to functional work in the delivery of information technologies as a specialist activity. Neither has the appropriate focus for office administration. A Bachelor of Administrative Systems degree, as implied in this article, would prepare creative, logical thinkers, with the intellectual power, breath of knowledge, and mental flexibility to work in partnership with other professionals and managers to realize the productive potential of the new computer-based technologies in the office.

A person with an office administration degree would be prepared to start his/her career as an administrative assistant, executive secretary, or document management specialist. But what is most important, as the organization evolves and the person matures in his/her skills, other work within the organization would be open - whether in personnel, sales, or supervision.

\section{CONCLUSION}

We have argued that economic, technological, and organizational imperatives suggest the need for locating office-support studies in the university system. We believe that there will be an increasing need for university graduates for office support and administrative jobs in the rapidly changing (learning) organizations of the 1990s. The intellective skills gained from their university studies will be the foundation for both organizational productivity and personal growth and career mobility. Although the issue is beyond the scope of this paper, the research 
conducted by faculty in universities will help point the direction for change in the structure and processes of office work in organizations.

Universities should be leading the educational transformation that is needed in both universities and organizations to exploit the power of the new technologies. That universities are currently abandoning education for the office is ironic given current needs and possibilities.

\section{NOTES}

1 Support for technology-driven organizational change is provided by A.C. Hax (1989). Building the firm of the future. Sloan Management Review, 75, 75-8; J.P. Kotter. (1988). The leadership factor. New York: The Free Press; I.I. Mitroff. (1987). Business not as usual: Rethinking our individual, corporate, and industrial strategies for global competition. San Francisco: Jossey-Bass; R.F. Monger. (1988). Mastering technology: A management framework for getting results. New York: The Free Press.

2 As reported in Mead, T. (199). The IS innovator at Dupont. Datamation, April 15, 61-66.

3 For a few years during the 1970 s, the introduction of text-generation technologies seemed to reduce the need for the secretary in her skills-support role. In keeping with the industrial-age thinking, the new office technologies were subsumed under the term "office automation."

4 See Walton, R.E. (1985, Mar-Apr). From control to commitment in the workplace. Harvard Business Review, 77-87.

\section{REFERENCES}

Curley, K.F. \& Pyburn, P.J. (1982). "Intellectural" technologies: The key to improving white-collar productivity. Sloan Management Review, 24, 31-39.

Hayes, R.H., Wheelwright, S.C., and Clark, K.B. (1988). Dynamic manufacturing: Creating the learning organization. New York: The Free Press.

Kanter, R.M. (1977). Men and women of the corporation. New York: Basic Books, Inc.

Rockart, J.F. and Short, J.E. (1989). IT in the 1990's: Managing organizational interdependence. Sloan Management Review, 75, 7-17.

Strassmann, P.A. (1985). Information payoff: The transformation of work in the electronic age. New York: The Free Press.

Zuboff, S. (1988). In the age of the smart machine: The future of work and power. New York: Basic Books, Inc. 


\title{
POUR LA CRÉATION D'UN PROGRAMME UNIVERSITAIRE EN BUREAUTIQUE
}

\author{
VIRGINIA SULLIVAN* ${ }^{*}$ et R. KENT YOUNG $\dagger$
}

\section{RÉSUMÉ}

Les auteurs montrent ici qu' au lieu d'abandonner l'enseignement des disciplines administratives servant à la formation du personnel de bureau, les universités devraient introduire les transformations nécessaires à leur formation en leur enseignant comment utiliser au mieux les nouvelles techniques informatiques. Leur point de vue se fonde sur quatre arguments. Premièrement, l'informatique telle qu' elle est utilisée dans les bureaux permet d'emmagasiner des données, ce qui donne la chance à des utilisateurs inventifs d'innover dans leur travail. La gestion d'une telle somme d'information exige du personnel, y compris les employé(e)s de bureau, des qualités dites «intellectives». Deuxièmement, les changements rapides auxquels doivent faire face les entreprises exigent un personnel flexible ayant un niveau intellectuel élevé qui lui permette d'aider le directeur à maintenir l'entreprise dans la compétition tout au long des années 90 et même au-delà. Troisièmement, alors que la relation stéréotypée patronsecrétaire fondée sur l'autorité évolue vers une relation d'association, le personnel administratif aura de plus en plus besoin de la formation intellectuelle que dispensent les universités. Finalement, en tant qu'élément clé de l'équipe de gestion d' une information particulièrement vaste, le personnel administratif doit avoir reçu une formation universitaire lui permettant de changer d' emploi au fur et à mesure que ses connaissances du métier et ses qualifications lui en donneront la possibilité.

Les années 80 se sont caractérisées par des changements nombreux dans les méthodes de production et de traitement de données du simple fait que l'économie s'est mise à dépendre de plus en plus de ce qui se faisait ailleurs dans le monde. Or, non seulement ces tendances persistent grâce aux progrès de l'informatique, notamment dans le domaine des communications et l'élaboration des bases de données, mais elles sont de plus à l'origine de nouveaux progrès. ${ }^{1}$

Nous croyons que les changements rapides de l'organisation des activités commerciales se répercutent directement sur le rôle du personnel administratif et des secrétaires. Nous sommes convaincus que l'apprentissage de ce rôle doit maintenant s'offrir à l'université de façon que l'on puisse bénéficier des nombreux avantages offerts par les nouvelles techniques issues de l'informatique.

*Division de l'éducation des adultes et de la formation professionnelle, Université du NouveauBrunswick.

$\nmid$ Département de l'administration des affaires Université Saint-François-Xavier. 
Notre intérêt pour l'enseignement des compétences propres au personnel administratif s'est encore renforcé lorsque nous avons pris part à l'étude organisée par le Département des études de secrétariat de l'université Saint-François-Xavier, petite université de premier cycle. À la suite de cette étude, le sénat de l'université a malheureusement décidé de fermer ce département plutôt que de le transformer. L'université Acadia, université de même nature que Saint-François-Xavier, de même que plusieurs petites universités américaines ont elles aussi récemment choisi de mettre fin à leurs programmes. d'études en administration et en secrétariat. D'autres universités ont en revanche supprimé le terme «secrétaire » de leur programme, ajouté des cours d'informatique et de communications, et abandonné l'enseignement de la sténo dans le but d'adapter leurs programmes aux exigences des années 90. L'University of Western Ontario, qui s'en allait dans cette direction, a tout compte fait décidé de mettre fin à son programme de gestion administrative et de le remplacer par un programme d'études informatiques et administratives.

Plusieurs facteurs vont à l'encontre de l'installation de programmes d'études administratives au sein des universités: le fait que les professeurs universitaires en arts ou en sciences ont peu d'estime pour les études ayant un caractère pratique; la croyance populaire chez les universitaires et les fonctionnaires que les connaissances pratiques s'acquièrent principalement par la répétition mécanique de certaines activités et qu'elles devraient par conséquent être prises en charge soit par l'employeur, soit par les collèges communautaires; le désaccord sur la question de savoir si les arts libéraux sont une connaissance, une technique ou les deux; les pressions auxquelles sont soumises les universités et qui les forcent à supprimer des départements pour réduire leurs dépenses; et enfin le caractère dépassé de bien des programmes universitaires en études administratives. Sur ce dernier point, on peut dire que les programmes de formation des secrétaires ont trop longtemps mis l'accent sur la dactylographie et la sténographie qui exigeaient un grand investissement de temps mais pouvaient difficilement être considérées comme des disciplines universitaires. De nos jours, en revanche, du fait de l'existence des nouvelles techniques de communications et d'informatique, l'importance de la dactylographie et de la sténographie a nettement pris du recul au bénéfice de compétences intellectuelles et relationnelles.

Cette conception qui prévaut encore sur les études de secrétariat s'accordait sans doute avec les principes de l'ère industrielle; mais de nos jours ces principes se sont transformés pour créer une nouvelle ère: celle de la connaissance et des services. Voilà pourquoi nous sommes convaincus qu'il est tout à fait vital que les universités offrent des programmes d'études administratives de haut niveau qui répondent aux exigences prévisibles d'un avenir proche, exigences fondées à la fois sur l'accroissement de la productivité grâce à une meilleure organisation et à une plus grande mobilité professionnelle de ceux et celles qui, en début de carrière, occupent un emploi administratif. Par ailleurs, la demande croissante en informatique, et l'effet qu'a celle-ci sur les activités et le rôle du personnel administratif (directeurs, techniciens et employés) montrent bien qu'il faudra 
former à tous les niveaux, y compris à celui des employé(e)s, un personnel disposant d'un niveau d'études plus élevé.

Raymond Cairns, vice-président des systèmes informatisés de DuPont, compagnie de pointe dans le domaine de l'utilisation des nouvelles techniques informatiques, fait sur cette question une remarque très révélatrice:

Ma secrétaire peut maintenant s'occuper de la présentation de tableaux ou de graphiques, de leur réalisation et de bien d'autres choses comme celles-là. Son rôle est très différent de ce qu'il était il y a huit ans et je pense que dans dix ans il sera de nouveau très différent de ce qu'il est aujourd'hui. Mais alors mon rôle aussi sera différent. ${ }^{2}$

Nous fonderons notre raisonnement pour convaincre qu'il est nécessaire d'offrir des programmes d'études administratives dans les universités sur quatre points qui caractérisent le monde du travail des années 90 : l'accès aux techniques informatiques; la nécessité de créer l'habitude d'apprendre chez tous les membres de l'entreprise; les changements fondamentaux de la fonction du personnel administratif; et l'importance d'offrir à ceux qui entrent dans le monde du travail par le biais d'un emploi administratif la mobilité professionnelle qui convient.

\section{LES TECHNIQUES INFORMATIQUES}

Paul Strassmann s'est fait une idée bien précise du pouvoir de transformation inhérent aux techniques informatiques alors qu'il dirigeait les systèmes informatisés chez Xerox. Dans son article intitulé «Information Payoff: The Transformation of Work in the Electronic Era » (Les avantages de l'informatisation, ou la transformation du travail à l'ère de l'électronique) Strassmann montre que l'économie des quatre grandes époques de l'humanité s'est fondée chaque fois sur une activité dominante: dans un premier temps, cette activité fut la chasse, c'est-à-dire que la nature était la ressource fondamentale; puis l'économie s'est fondée sur l'agriculture si bien que la terre est devenue la ressource principale; ensuite, elle s'est fondée sur l'industrie et le capital est devenu la ressource numéro un; enfin, l'économie se fonde aujourd'hui sur les services, et c'est l'information qui en est la grande ressource. Strassmann prévoit donc que les gains de productivité ne pourront se faire qu'au moyen d'une formation continue. L'investissement le plus important sera donc celui de la formation des « ressources humaines".

Strassmann prétend de plus que les habitudes de travail et les modes de gestion qui étaient efficaces à l'ère industrielle ne permettront plus de réussir dans une économie axée sur les services. Les emplois simples, standardisés, séparés mais très surveillés, efficaces à l'époque industrielle, devront faire place à des emplois exigeant une compétence individuelle, des connaissances variées, de l'autonomie et l'acceptation de nouveaux apprentissages chaque fois que cela sera nécessaire pour obtenir de nouveaux gains de productivité.

Par ailleurs, Strassmann affirme que l'informatisation permet de relever le niveau des fonctions administratives. Il prévoit que les directeurs deviendront des 
planificateurs au lieu d'être des investisseurs, que les chefs de bureaux passeront de coordinateurs à investisseurs et que le personnel technique et professionnel, au lieu d'être spécialisé dans un domaine particulier, sera compétent dans l'ensemble des services liés à l'information. Quant à la fonction de l'employé(e) de bureau, elle se transformera de façon à comprendre «un grand nombre des activités spécialisées actuellement réalisées par le personnel technique et professionnel. »

Dans un autre article publié en 1982 et intitulé « Intellectual Technologies: The Key to White-Collar Productivity » (Les techniques intellectuelles comme clé de la productivité des employés de bureau), Kathleen Curley et Philip Pyburn prédisaient aussi le passage de l'ère industrielle à celle des services informatisés et expliquaient quelles seraient les conséquences de cette dernière sur le travail de bureau et sur la formation du personnel. Ils y faisaient en outre une distinction entre techniques «industrielles» et techniques «intellectuelles». Les techniques industrielles exigeraient selon eux une formation de «Type $A$ », c'est-à-dire l'apprentissage «d'un certain nombre de connaissances prédéterminées, décidées à priori et standardisées. " Ce type de formation convient au travail de bureau tel qu'il a été conçu à l'ère industrielle; il comprend la dactylographie, la sténographie, le classement de dossiers et autres activités de ce genre qui ont fait dire des programmes d'études administratives enseignés dans les universités qu'ils étaient dépassés. Au contraire, les techniques intellectuelles fondées sur l'emploi de l'ordinateur n'ont de limites que celles de l'imagination de l'utilisateur dont elles renforcent encore la capacité intellectuelle. Les techniques intellectuelles demandent à la fois une formation de type A et de type B: de type A pour apprendre à se servir de la machine (exigence de moins en moins difficile à réaliser depuis que l'utilisation d'icônes tend à se normaliser) et de type B pour comprendre les divers moyens d'utilisation de la machine. L'apprentissage de type $B$, analytique et conceptuel, facilite une adaptation continue à la machine et la création d'applications nouvelles. Les résultats que l'on obtient à la suite d'un apprentissage de type B ne sont pas connus d'avance du fait même que ce dernier fait intervenir certaines variables telles que l'imagination de l'utilisateur et son savoir-faire. Seul un enseignement universitaire est capable de fournir un apprentissage de type $B$.

Shoshana Zuboff a encore approfondi notre connaissance des transformations techniques (nouveautés et ruptures) qui sont en train de se produire et annoncent l'avenir. Son livre, intitulé In the Age of the Smart Machine: The Future of Work and Power (Quand la machine sera intelligente, ou le travail et la puissance), se fonde sur une analyse longitudinale du travail informatisé dans plusieurs entreprises. Zuboff fait une distinction entre le pouvoir d'automatisation des techniques informatiques et celui d'information. Vers la fin de l'ère industrielle en effet, c'est-à-dire avant l'utilisation des puces informatiques, les ordinateurs servaient à l'automatisation, c'est-à-dire qu'il s'agissait de remplacer l'effort humain, à la fois en milieu industriel et en milieu administratif. ${ }^{3}$ La présentation de Zuboff des «bases de données comme substituts de gestion » a pour but de mettre l'accent sur la capacité des ordinateurs à retenir, accumuler et afficher des données 
fines, capacité qui représente l'ensemble des activités de production et de commercialisation. Elle crée le terme «informant» pour expliquer le type de travail que l'utilisateur intelligent et inventif peut faire lorsqu'il est capable d'associer certaines de ces données. De nouvelles idées peuvent naître d'une question bien posée et produire de nouveaux procédés ou de nouveaux produits. Les capacités "informantes » de l'informatique permet aux utilisateurs intelligents de gagner sur le terrain de la compétition des années 90 , qui sera celui de la productivité et de l'innovation.

Les deux applications de ces techniques (l'automatisation et l'information) reflètent les deux types d'utilisateurs auxquels elles s'adressent: soit un personnel aux qualifications banales dont les activités étaient, vers la fin de l'ère industrielle, prévues à l'avance grâce à une machine intelligente, soit un utilisateur intelligent qui sera capable, à l'ère déjà commencée de l'information, de tirer le maximum de sa machine.

Pour utiliser les techniques informatiques avec efficacité et s'adapter comme il convient aux changements visibles du milieu du travail (méthodes et relations professionnelles), il faut que l'utilisateur soit intelligent quel que soit le niveau qu'il occupe au sein de l'administration, qu'il soit à un poste d'exécution ou à un autre. Le personnel administratif doit se servir régulièrement des données disponibles; on attend de lui qu'il fasse preuve d'intelligence quand il s'agit de résoudre des problèmes qui dépendent de lui. Les membres de ce personnel ont besoin de ce que Zuboff a appelé des «capacités intellectives », capacités qui regroupent la capacité d'abstration, le raisonnement inductif et la conceptualisation. Ces capacités ne sauraient être produites ailleurs que dans des universités.

\section{L'ENTREPRISE EN FORMATION CONTINUE}

Dans le livre intitulé Dynamic Manufacturing: Creating the Learning Organization (Pour une industrie dynamique, la créaction d'une entreprise en formation continue), Hayes et ses collègues de l'université Harvard ont employé l'expression «entreprise en formation continue» pour attirer l'attention sur la qualité essentielle des industries qui seront capables de s'adapter au contexte économique des années 90 . Ces entreprises s'engagent en effet à améliorer sans cesse le produit qu'elles offrent à leur client et à favoriser la simplification des procédés et la discipline interne de l'entreprise. Hayes et ses collègues croient que ce type d'entreprise devrait être le but que toutes les organisations soumises à la transformation rapide des marchés financiers, des techniques et des modes de gestion ainsi qu'à la compétition, devraient se fixer. «L'entreprise en formation continue " demande à tous ses employés de posséder un haut niveau de capacités intellectuelles en plus de s'engager fermement à apprendre sur une base continue.

Rockart et Short du Centre for Information Systems (M.I.T. Sloan School of Management) ont trouvé à la suite de l'étude de seize grandes entreprises, que le rôle des cadres supérieurs devenait de plus en plus complexe au fur et à mesure que les changements s'intensifiaient et qu'ils ou elles devaient agir même lorsque les 
lignes de conduite ou les décisions n'étaient pas clairement définies. Ces cadres supérieurs doivent avoir des adjoints compétents dans leurs bureaux pour pouvoir concentrer leurs efforts sur des stratégies générales, des activités de représentation de l'entreprise à l'extérieur ainsi que sur la planification des changements à instaurer pour que celle-ci reste compétitive.

Le personnel administratif (employé(e)s, administrateurs ou administratrices) doit tenir compte de deux aspects fondamentaux du fonctionnement d'un bureau: d'une part la mise en place des nouvelles techniques administratives et leur exploitation (gestion dẹs données contenues dans un ordinateur et utilisation des nouvelles techniques de communication), et d'autre part la répartition complexe des tâches et l'organisation des relations à établir entre elles. Le personnel administratif doit donc posséder les qualités de conceptualisation, d'analyse et de communication interpersonnelle que l'on associe traditionnellement à l'enseignement universitaire afin de pouvoir communiquer aussi efficacement avec les techniciens responsables de l'amélioration constante des techniques administratives qu'avec tout le réseau de personnes qui gravitent autour du responsable.

\section{ÉVOLUTION DU RÔLE DU PERSONNEL ADMINISTRATIF}

Il semble à la mode de dénigrer le rôle des employé(e)s de bureau en le qualifiant de servile et en soulignant que les universités n'ont pas pour but d'enseigner la servilité. En fait, le travail de bureau à l'ère industrielle, en se fondant sur l'utilisation des machines à écrire et de la sténographie, menait bien à un certain asservissement. Dans son livre intitulé Men and Women of the Corporation (L'homme et la femme dans les sociétés commerciales), Rosabeth Kanter décrit comment, vers 1900, ce rôle s'est élaboré: à cette époque, les grosses sociétés de l'ère industrielle exigeaient des spécialistes du commandement. Le directeur idéal était alors généralement de sexe masculin, dur, à l'esprit rationnel et analytique. Les femmes sont tout d'abord entrées dans les bureaux pour y être sténo-dactylos, comptables ou employées aux écritures. Plus tard le rôle de secrétaire est apparu comme un rôle de relations publiques fondé sur des qualités personnelles telles que le dévouement. Kanter se demande si la relation qui s'est ainsi établie entre les secrétaires et leur directeur n'est pas «un exemple typique de reproduction du modèle patriarcal dans le milieu du travail ». Dans ces conditions, la mobilité professionnelle des secrétaires, leur salaire et leur pouvoir dépendaient bien plus de leur chef, de son statut et de ses prétentions, que de leurs qualifications, éducation ou expérience. Kanter croit que c'est pour cette raison que le rôle des secrétaires s'est trouvé défini par des caractéristiques de type esprit de clocher, timidité, caractère effacé, besoin maladif de compliments et émotivité. Il n'est donc pas surprenant que le rôle des secrétaires et l'enseignement qu'on leur dispense (aucun des deux n'ayant été jusqu'à présent fondés sur les besoins du bureau de demain) soient relégués si bas dans l'estime des étudiants, des professeurs d'université et d'un grand nombre de directeurs dont les idées se sont formées à l'ère industrielle et se sont renforcées par leur propre réussite. De nos 
jours pourtant il faut revoir la relation directeur-employé(e) et la transformer en un contrat d'association non fondé sur la hiérarchie; tout le potentiel de productivité pourra ainsi être mis en ouvre, comme le souligne Walton à propos de la relation qu'il faut établir entre les directeurs et les autres professionnels. ${ }^{4}$ Une formation fondée sur l'acquisition des qualités «intellectives " nécessaires à la mise en place d'un travail constructif tant du point de vue technique que relationnel, est incontestablement du ressort de l'enseignement universitaire.

\section{LA MOBILITÉ PROFESSIONNELLE}

Nous avons montré que l'employé(e) de bureau est un élément clé dans une équipe de gestion de l'information que caractérisent de vastes connaissances. Pour favoriser l'acquisition des qualités «intellectives» susceptibles d'apporter une contribution efficace, il faut que l'enseignement soit plus exigeant et non le contraire. De plus, les jeunes, hommes et femmes, qui souhaitent exercer une profession administrative devraient pouvoir faire leurs études en milieu universitaire de façon à ne pas se trouver dans l'incapacité de les poursuivre au moment où ils seront prêts à assumer d'autres responsabilités dans leur entreprise simplement parce que leurs premières études ont été insuffisantes.

Les connaissances de base des bons employés de bureau ne sauraient être acquises dans les programmes que les universités offrent actuellement en Administration des affaires ou en Informatique. En effet, ces programmes ont pour but de donner aux étudiants des notions de gestion ou alors de leur transmettre suffisamment de connaissances pour qu'ils ou elles puissent travailler en tant que spécialistes dans le domaine de l'informatique. Aucune de ces deux orientations ne prépare convenablement à un emploi de bureau. En revanche, un baccalauréat en bureautique, conçu selon les principes exposés dans cet article, permettrait de former un personnel habitué à penser avec logique mais sachant aussi utiliser son imagination; ces personnes auraient en outre de bonnes capacités intellectuelles, le goût d'apprendre et une flexibilité suffisante pour leur permettre de travailler en collaboration avec les autres professionnels et avec les directeurs. Le bureau atteindrait alors le maximum du potentiel de productivité des techniques informatiques.

Les titulaires d'un diplôme en bureautique commenceraient peut-être leur carrière comme auxiliaires administratifs, secrétaires de direction ou spécialistes de la gestion des données. Mais ce qui est le plus important, c'est qu'au fur et à mesure que l'entreprise évoluerait ceux-ci se perfectionneraient et assumeraient d'autres responsabilités, soit dans la gestion du personnel, soit dans les ventes ou le contrôle.

\section{CONCLUSION}

Nous avons montré combien les impératifs économiques, technologiques et structurels rendent évidente la nécessité d'offrir des programmes de formation en administration au niveau universitaire. Nous croyons qu'il faudra de plus en plus 
de diplômés de l'université pour occuper les emplois nouveaux qui se créent à l'heure actuelle au sein des entreprises (en formation continue), entreprises en pleine transformation dans les années 90 . Les qualités « intellectives » que seules les universités sont capables de stimuler, seront le meilleur fondement pour parvenir à une bonne productivité tout en offrant au personnel administratif des occasions de perfectionnement individuel et de mobilité professionnelle. Quoique la question dépasse l'objet de cet article, il est permis de penser que les recherches que les professeurs d'université mèneraient alors permettraient de voir de plus dans quelle direction ces changements pourraient aller.

Alors les universités joueraient un rôle de chef de file en se faisant les instigatrices des transformations à introduire tant dans les programmes universitaires que dans les entreprises pour utiliser au mieux la puissance offerte par les nouvelles techniques. Il semble donc tout-à-fait contradictoire que l'université abandonne l'enseignement de la bureautique juste au moment où l'on prend conscience des besoins actuels et des possibilités qu'un tel enseignement lui offrirait.

\section{NOTES}

1 Les sources utilisées à l'appui de la présentation des changements structurels dus aux nouvelles techniques sont les suivantes: A.C. Hax (1989): «Building the firm of the future» (L'entreprise de demain). Sloan Management Review, 75, 75-8; J.P. Kotter. (1988). The leadership factor (Le facteur d'avancement). New York: The Free Press; I.I. Mitroff. (1987). Business not as usual; Rethinking our individual, corporate, and industrial strategies for global competition (Concevoir un monde commercial différent, ou comment revoir nos stratégies industrielles, commerciales et personnelles à l'ère de la compétition internationale). San Francisco: Jossey-Bass; R.F. Monger (1988). Mastering technology: A Management framework for getting results (Maîtriser la technologie, ou comment établir un cadre de gestion qui donne de bons résultats). New York: The Free Press.

2 Voir Mead, T. (1990) «The IS innovator at Dupont. " Datamation, 15 avril, 61-66.

3 Pendant quelques années, dans les années 70 , on a cru que l'introduction des techniques de traitement de textes allait réduire le rôle des secrétaires puisque cela touchait leur domaine. À cette époque et conformément à la façon de penser de l'ère industrielle, on considérait en effet que ces nouvelles techniques se résumeraient à une plus grande automatisation du bureau.

4 Voir Walton, R.E. (1985, mars-avril) «From control to commitment in the workplace » (Après le contrôle, l'engagement en milieu de travail) Harvard Business review, 77-87. 